\section{Botanical collections at risk}

SIR - We wish to draw your readers' attention to the outcome of an important conference held by UNESCO and the International Council of Scientific Unions (ICSU) at the Komarov Botanical Institute in St Petersburg in December 1993. Among other things, the status and the future of botanical collections in the former Soviet Union were discussed.

There are more than 25 million plant specimens, living and preserved, in more than 230 collections in the former Soviet Union. These constitute a botanical resource of incalculable international importance. Because of chronic underfunding, these collections are at immediate risk of irreparable damage from unsuitable and deteriorating storage conditions such as inadequate pest control and fire precautions. Use of the collections is hampered by insufficient staff (some have no staff at all), inadequate curation and the impediments to the loan and exchange of specimens caused by an expensive and unreliable postal system. There is little hope of an improvement of state funding in the near future. Staff morale is low.

These problems must be of great concern to the international botanical community. Apart from money, the collections are urgently in need of the skills necessary for planning and ensuring their long-term survival. The conference recommended the following actions:

- The appropriate authorities should assume full responsibility for collections on their territories.

- UNESCO should plan an international programme in the field, and should declare an official Year of Natural History Collections to that end.

- The public, governments and international institutions should be made aware of the importance of the collections; they and donor agencies should develop programmes to support the collections.

- The Komarov Botanical Institute should be designated a part of the Russian National Heritage.

- Botanical institutes within the former Soviet Union should produce inventories of their collections and make the information available internationally.

- Each collection should develop a statement of its goals and a realistic plan for achieving them.

International collaboration should be strengthened by the improved exchange of material and information as well as by staff training in herbarium management, through the Panarctica Biota project and

Letters submitted for Correspondence should be typed, double-spaced, on one side of the paper only.

NATURE · VOL 371 • 1 SEPTEMBER 1994 the development of computerized databases.

In our opinion, the institutes responsible for botanical collections in the Soviet Union need not only financial assistance but also help in formulating and executing plans for the future. They need to learn how to fight for their own survival.

D. S. Ingram

Royal Botanic Garden,

$20 A$ Inverleith Row,

Edinburgh EH3 5LR, UK

G. LI. Lucas

The Herbarium,

Royal Botanic Gardens, Kew,

Richmond, Surrey TW9 $3 A E$, UK

R. Huxley

Department of Botany,

Natural History Museum,

Cromwell Road, London SW7 5BD, UK

\section{Medicinal plants}

SIR - B. K. Holland's Commentary, "Prospecting drugs from ancient texts"1 proposes a re-examination of GraecoRoman pharmacological literature to screen for drugs of potential therapeutic use. This important proposal raises three problems that deserve consideration.

First, a philological problem. Although some aspects of Graeco-Roman pharmacology have been studied in depth - for example, its relationship to folklore on the one hand and literate learning on the other ${ }^{2}$ - technical texts such as collections of recipes and drug handbooks have attracted much less attention from philologists and historians of medicine. As a result, only a limited number of old (and sometimes outdated) critical editions of these texts are available. This is true not only of writers considered, rightly or wrongly, to be of secondary importance (for example, Marcellus of Bordeaux ${ }^{3}$ and Theodorus Priscianus ${ }^{4}$ ), but also of acknowledged masters of ancient botany and medicine such as Dioscorides and Galen. For example, the reader interested in Dioscorides' Euporista, a short handbook that classifies hundreds of medicinal plants on the basis of their therapeutic usage, must still depend on the edition published by $C$. G. Kuhn more than a century and a half ago (1830).

It is hardly surprising, then, that many anonymous libri receptarii, lists of drug prescriptions written in Latin as well as in vernacular languages between the fourth and eleventh centuries, are still awaiting publication $^{5,6}$. Finally, even when adequate critical editions exist, as in the case of Pseudo-Apuleius' Herbarius ${ }^{7}$, few translations are available, making these works of little use to researchers who do not have a solid background in Greek or Latin.
The second problem is one of plant identification. How do we establish the identity of medicinal plants mentioned in texts that, as a rule, provide no iconography and only cursory botanical descriptions? Although the works of Theophrastus and Dioscorides provide a firm starting point and have made possible the compilation of important repertories of classical phytonims ${ }^{8}$, several problems remain. For example, how confident can we be that the same plant name used in the second century BC by the Italian Cato the Elder and in the fourth century AD by the North-African Pseudo-Apuleius indicate the same botanical species? Clearly, a detailed analysis should be carried out to confirm, case by case, the most plausible identifications.

The third problem, and possibly the most delicate, is one of historical perspective. We are used to thinking of pharmacological therapy as something exclusively rational and experimental. This may or may not be true for current therapy, but it is certainly false for premodern therapy. Like us, the Ancients believed in the value of experimental evidence. But they attributed to this deceptively simple concept meanings which, beside being widely different from our own, also changed considerably during the sixteen centuries that separate Hippocratic writers from, say, Hildegard of Bingen. Yet appreciating the various elements that made up premodern therapeutic choices - sometimes an assembly of empirics, philosophy and folklore - is essential to finding the way through the intricate pharmacopeias of the Ancients.

In conclusion, Holland's proposal opens up a promising avenue of research that may lead to the discovery of novel therapeutic agents (or rather, to the rediscovery of ancient ones). The problems outlined here underscore the importance, pointed out by Holland ${ }^{1}$, of carrying out this research through a multidisciplinary effort involving specialists from such diverse fields as philology, botany, pharmacology and history of medicine.

\section{Daniele Piomelli}

Unité de Neurobiologie

et Pharmacologie de I'INSERM,

Paris, France

Antonino Pollio

Dipartimento di Biologia Vegetale,

Università Federico II,

Napoli, Italia

1. Holland, B. K. Nature 369, 702 (1994).

2. Lloyd, G. R. Science, Folklore and ldeology, 112-217 (Cambridge University Press, 1983).

3. Marcellus Empiricus De Medicamentis (ed. Elmreich, G.) (Teubner, Lipsia, 1889).

4. Theodorus Priscianus Euporiston (ed. Rose, V.) (Teubner, Lipsia, 1894)

5. Sigerist, H. E. Bull. Hist. Medicine 2, 26-52 (1934).

6. Stannard, J. Bull. Hist. Medicine 46, 455-467 (1972).

7. Sigerist, H. E. \& Howald, E. Pseudo-Apulei Herbarius Corpus Medicorum Latinorum, vol. IV (Leipzig and Berlin, 1927).

8. André J. Les Noms des Plantes dans la Rome Antique (Les Belles Lettres, Paris, 1981) 